\title{
The Allocation of Village Fund as a Basis for Decentralization in the Region
}

\author{
Sylvina Rusadi \\ Universitas Islam Riau \\ Pekanbaru Indonesia \\ E-mail: sylvinarusadi@soc.uir.ac.id
}

\begin{abstract}
Decentralization is one of the authorities given to the region in managing their own household. Villages are considered as areas that have an important role in assessing the success of a state. For that is needed to be a independence for the village in managing its own finance. One of the authorities is trough the village fund allocation. The village fund allocation is the financial gain of the village from the district trough the village stash. The village fund allocation is very important because the policy of the village fund allocation is in line with the regional autonomy agenda where the village is the basis of Decentralization. However, in the course of the village fund allocation still found the problems of not achieving the objectives of its in financing the empowerment and development of the village, because the village fund allocation is only used as a source of income for the village head and village apparatuses plus no control of the village community. For that, its needed the supervision of the village community itself.
\end{abstract}

Keywords: Decentralization, Authority, Allocation of Village Fund

\section{INTRODUCTION}

In the framework of the State's efforts in achieving the purpose of the welfare of the nation as stipulated in the preamble of the 1945 Constitution required the existence of an authority given to regions in managing their own finances. This is important because in a listed authority of the rights of the region itself in managing finances that Tetu course can be adapted to the context of the economic, demographic, social and culture of each region. This is where the importance of decentralization, decentralization can create a society that has a relatively independent life awareness to control and manage the environmental conditions in which they are located.

As described in Law No. 23 of 2014 on Regional Government Article 1 (1) which says that the Republic of Indonesia is divided over the province, and the province was divided over the District and the City. Regional District as a unit of government organizations that have a number of compulsory affairs as stipulated in Article 9 of Law No. 23 of 2014 obligatory functions under the authority of the local government district / city include:
1. government affairs consisting of absolute affairs, government affairs concurrent, and government affairs public.

2. Affairs concurrent administration has been decentralized into a basic implementation of regional autonomy.

3. The general government affairs referred to in paragraph (1) is a government affairs under the authority of the President as head of government affairs

4. absolute rule referred to in paragraph (1) is a matter government was the full authority of the central government.

5. affairs concurrent administration as referred to in paragraph (1) is the central and local government affairs Provincial and Regency / City.

As the smallest part of the district administration, the village also has the powers contained in the Act No. 6 of 2014 on the village of Article 19, which reads:

1. The authority under the right origin

2. Local authoritiespowers-scalevillage

3. The commissioned by the government to be, provincial government or the Regency / City

4. Additional Authority assigned by the government, provincial government or regency / municipality in accordance with the provisions of the legislation.

One authority given area is the village-scale local authority meant above provide opportunities for rural communities in managing their own finances as stated in Law No. 6 of 2014 on the village where the article 72 paragraph 1 states the village revenue derived from:

1. Village revenue consists of operating results, the results of assets, self-help and participation, mutual help, and others revenues Village;

2. The allocation of the State Budget;

3. Part of the results of local taxes and levies Regency / City; 
4. Village Allocation Fund which is part of the balance funds received by district / city;

5. Financial assistance from the Budget of the Regency / City;

6. Grants and donations are not binding on third parties; and other legitimate income of the village.

Village Fund Allocation referred to as one of the sources of income of the village, further acquisition of Village Allocation Fund is part of the District Rural finance the cash distribution through the village. Village Allocation Funds are intended to finance government programs in the village of governance and development and community empowerment.

\section{DISCUSSION}

Village Allocation Fund is one form of authority given to the village, this authority is considered essential to foster selfreliance as a base Decentralized Rural communities in the area. Village Allocation Fund is basically aimed at the development and welfare of the community, but problems often arise Village Allocation Fund as a result of misuse of fund allocation by the village chief and his village of the device. The aim of the Authority is no longer possible because the majority of Village Allocation Funds earmarked for operational and recurrent expenditure alone. Lack of surveillance is also a point of issue in the Management of Village Allocation Fund, society as a watchdog here to participate less so the lack of control for policy holders.

To understand this paper the authors will present concepts that can support our understanding of all the Village Fund Allocation as a base Decentralization in the area.

\section{A. The concept of decentralization}

As a unitary state that adheres to the principles of decentralization in organizing his administration, the central government gives leeway and authority to the regions to organize regional autonomy. The second change article 18 of Law 1945 states inter alia that "the unitary state of the Republic of Indonesi divided into areas of the Province and the province was divided over the District and the City, which each have a local government that is set by the Law".

In accordance with Article 18 of the Constitution of 1945, the system of government in Indonesia recognize the existence of the central government and local governments. Formation of regional administration based on the condition of the territory of a very broad, covering a variety of islands, people have the same cultural background, and so on, resulting in difficulty of governance if everything is taken care of by the central government based in the national capital. To take care of governance more effectively and efficiently. [1]

Decentralization is the devolution of government power to local governments to regulate and manage all matters of government in the system of the Republic of Indonesia [2]

\section{B. The concept of Village Allocation Fund}

Hidayanto Simanjuntak said that the formulation of the allocation of funds must have a sufficiency nature, flexible and stable. Sufficiency means the allocation of funds to cover the funding requirements of local government. Flexible means that the amount of funds allocated according to the ability of the central government, while stable means that the certainty for local governments in obtaining the allocation of funds. [3]

According Sahdan Village Allocation Fund is a fund to finance the responsiveness of state authority of the village, the village authority include: (a) authorizes the origin (natural resource management, indigenous justice, formed the original order, preserve local institutions) recognized (recognition) by the State; (b) The authority of local organizations attributive (planning, spatial, ecological, settlements, forming local organizations and others) established by the government through the Law; (c) discretionary-administrative Authority of delegation or co-administration of the government. [4]

According HAW Widjaja Village Allocation Fund is to increase empowerment, welfare and equitable development in rural areas through the budget funds district, provincial and central government, district, provincial and national need to realize budget funds amounting to $10 \%$ for the Village Fund Allocation. [ 5]

Rural Finance 3.Konsep ccording to theHAW Financial Widjadja village is a village government insists on the principles of democracy, public participation, equity and justice as well as considering the potential and diversity of the regions. The village has a very strategic position, so that the necessary attention that balanced on the implementation of regional autonomy. (6)

Hanif Nurcholis explained that village finances are all rights and obligations in respect of the village government that can be valued in money, referred to in it all forms of wealth related to the rights and obligations of the village. [7]

In the financial management area Mardiasmo states the principles underlying dalah:

\section{a) Transparency}

Transparency or openness here gives the sense that members of the public have equal rights and equal access to know the budget process for the aspirations and interests of the community, especially the fulfillment of the needs of life much , Merupaknan transparency principles that must exist and include the entire financial management good part of the planning process and implementation.

\section{b) Accountability}

Accountability is the principle of public accountability, which means that the budgeting process from the planning, preparation and execution should really be reported and accounted for to BPD and society. People not 
only have the right to know the budget but also have the right to demand accountability for the implementation of the plan or the budget.

\section{c) Value for money}

This principle means that the implementation of the three principal in the budgeting process that is economical, efficient, and effective. Economics deals with the selection and use of resources in a certain quantity and quality at a cheap price. Efficiency means that the use of public funds that can produce the maximum output (useful). Effectiveness means that the use of the budget must achieve the targets or objectives of public interest. [8]

\section{CONCLUSION}

Village Fund Allocation problems can be solved if there is transparency, accountability, and the most important is the social control of the communities themselves. Villagers should foster a sense of belonging to the village, so that mistakes in the management of the Village Fund Allocation does not happen again. The role of community leaders is also crucial in supporting community participation.

\section{REFERENCES}

[1] Act of 1945, Section 18 of the Local Government

[2] Act 32 of 2004 Section 1 About the Local Government

[3] Robert A. Simanjuntak and Djoko Hidayanto, General Allocation Fund in theHome.Jakarta: Kompas Hlm.158

[4] Sahdan, Goris et al, Handbook Village Fund AllocationGuidelines.Bandung: FPPD 2002, hlm.10

[5] HAW Widjaja, Village Autonomy Autonomy is an Original, Round andWhole.Jakarta: King Grafindo Persada 2005, hlm.133

[6] Ibid

[7] Hanif Nurcholis, Growth and Governance VillageGovernment.Jakarta; Erland, 2011, hlm.81

[8] Mardiasmo, Autonomous and Local Financial Management.Yogyakarta: Andi 2002, hlm.105 